\title{
DISCIPLINE IN EDUCATION: CAUSES AND POSSIBLE STRATEGIES TO CURB EXAMINATION MALPRACTICES IN SENIOR HIGH SCHOOLS
}

\author{
Ben Adzrolo ${ }^{1}$, \\ Kenneth Asamoah-Gyimah', \\ Andrews Cobbinah ${ }^{3}$, \\ Ruth Annan-Brew ${ }^{4 i}$ \\ ${ }^{1}$ Department of Education and Psychology, \\ University of Cape Coast, \\ Ghana \\ 2,3,4 PhD, Department of Education and Psychology, \\ University of Cape Coast, \\ Ghana
}

\begin{abstract}
:
This paper investigated the causes and possible strategies to minimize examination malpractices in Senior High Schools (SHSs) in Ghana. A descriptive survey design with a quantitative approach was used for the study. Proportional stratified and simple random sampling techniques were used to select a sample of 335 respondents which comprised 302 students and 33 teachers. Frequencies, percentages, means and standard deviations were used to analyse the data gathered. The findings revealed that the leading cause of examination malpractices was 'insufficient students' preparation for WASSCE and Public education on effects of examination malpractices has also emerged as the number one strategy to minimize the menace. It was concluded that in schools where a conducive environment and teaching/ learning materials are not provided for effective academic work, performance falls below what is expected, to achieve academic success, students and teachers engage in examination malpractices to raise the academic image of the school. It was recommended that school authorities provide a conducive teaching and learning environment to ensure effective academic work in schools to minimize the menace.
\end{abstract}

Keywords: examination, examination malpractice, cheating, ranking, strategies, causes, invigilator

i Correspondence: email ruth.keziah@ucc.edu.gh 


\section{Introduction}

The examination has generally been recognised as the best form of assessment but the regular and widespread incidence of examination misconduct these days has called for attention (Christian, 2015 \& Makaula, 2018). According to Petters and Okon (2014) and Makaula (2018), records of examinations are labelled with many complaints by stakeholders in education about forms of examination malpractices and in most of these examination misconducts, cheating is a persistent incidence. According to Nyamwange, Ondima and Onderi (2013), Cheating in examinations is a global phenomenon that needs to be fought. Adams and Esther (2013) and Nyandwi (2017) supported this opinion by saying, it is very sad that many countries around the world today are plagued with examination cheating in their educational systems. In the words of Anderman and Midgley (2016), approximately $80 \%$ of great-achieving students of high schools and 75\% of students admitted to colleges have ever cheated in examinations. Isangedighi (2007) claimed that the growing cases of examination malpractice investigation among currents youth pose a major challenge to today's society. Examination malpractice has been defined and described variously by many authorities in the field of education. According to Omonijo (2010), examination malpractice is careless, unlawful or undesirable actions put up by candidates in any official assessment of his or her intellectual capability in a specific subject. Jega (2006) saw examination malpractice as any form of misbehaviour that leads to the alteration of or tampering with the prescribed ways of examining any given system. Chukwuemeka (1982) referred to examination malpractice as a violation of examination rules and regulations by candidates.

In the words of Asante-Kyei and Nduro (2014), examination malpractice is a thoughtful practice of misconduct by stakeholders including academics authority, students, teachers, and parents before the examination, during examination and postexamination to lift the academic image of the students and the school in the evaluation and assessment. According to Busayo (2008), cheating in an examination is an inappropriate and fraudulent way to obtain an undeserved advantage over the other candidates. To Bruno and Obidigbo (2012), examination malpractice is any act which the stakeholders in education; teachers, parents, students or educational administrators carry out to inflate the grades of the students in examination results. This phenomenon makes the assessment unreliable and unproductive in the face of the educational system. Any form of misconduct in examinations is regarded as examination malpractice in the educational system (Maheko, 2015). In the words of Saraj (2006), examination malpractice is an unsuitable and untruthful action that is connected to examination to acquire an unjustified benefit.

Onyechere (2008) found that the factors that cause examination malpractice include: students' lack of adequate preparation for the examination, desire to pass the examination at all costs, non-completion of syllabi, laxity in prosecuting offenders, inadequate funding of schools and ineffective teaching and learning. Adebayo (2012) indicated in his study that students involve themselves in examination malpractices 
because they believe that other students also engage in the menace. Suleman, Gul, Ambrin and Kamran (2015) conducted a study and found out that corruption, careless implementation of examination rules, inappropriate monitoring of examinations, students and parental intimidation, insufficient preparation for examinations and collusion were the causes of examination malpractices.

To minimise examination malpractices, Ene and Ursula (2015) opined that the government must make available conducive teaching and learning environments in educational institutions. This should be done by providing teaching and learning materials and also enhance teachers' salaries to stop ceaseless strike actions. According to Fagbemi (2011), appropriate orientation of stakeholders in education on examination misconduct and its influences should be held by the government, examination bodies and educational institutions to minimise EM. To Fagbemi, there should be a change in the sitting arrangement of students in an examination hall daily as well as a change of invigilators and supervisors. Fagbemi further stated that examination should be conducted in a ratio of one invigilator to twenty students to control the students.

Most stakeholders in educational sectors indulge in examination malpractices. Joshua (2010) identifies the following stakeholders as agents of examination malpractices:

\section{a. Students}

Most students do not prepare well for high-stake examinations such as WASSCE. Because these students lack the confidence to pass the examination, they resort to cheating in examinations to have good grades that they have not toiled for.

\section{b. Teachers}

Some teachers in Senior High Schools have the habit of assisting candidates during examinations, especially those who failed to complete syllabi and lessons before examination due dates. They solve questions and give them to the invigilators to be given to the candidates in the examination halls.

\section{c. Parents and Guardians}

Parents become syndicates in perpetrating examination malpractices. Money is provided to the wards by their parents to be given to the examination invigilators for them to allow their wards to cheat in examination to get good grades.

\section{d. Administrators of school}

Some headmasters or headmistresses and principals of schools indulge in examination cheating to obtain a hundred per cent $(100 \%)$ pass in public examinations to lift the academic image of the school.

\section{e. Government}

Government unknowingly and indirectly contributes to examination malpractices as a result of failure to provide adequate infrastructure and teaching/learning materials to schools and poor remuneration for teachers.

\section{f. Examination officials}

Examination officials fail to enforce the rules and regulations of examination simply because they are paid to allow candidates to cheat in examinations. 


\section{Statement of the Problem}

The issue of examination malpractices continued to be a matter of concern in education. The incidence of examination malpractices in the educational system at any given level poses a great threat to the reliability and validity of educational assessment (Adebayo, 2012 \& Abuga, 2015). Examination malpractice has been studied by Yusuf and Bamgbose (2015), Mutinda (2017) and Makaula (2018) and found out that desire to pass the examination at all costs, ranking of schools' performance and indiscipline among students cause EM. Similarly, studies conducted by Asante (2014), Dzakadzie (2015) and Otoo (2018) showed that inadequate teaching and learning materials, indiscipline among students and lack of adequate preparation toward examinations were found to be the causes of examination malpractices. Despite the high premium placed on examinations by the National Policy on Education, it seems that examination malpractice has not been addressed properly in Ghana. Common observations made in examinations indicated that there is mass cheating in external examinations such as WASSCE but nothing concrete is being done to minimise the problem except the cancellation of entire results or withholding of results in certain subjects. This work intended to find a lasting solution to the issue of examination malpractices among Senior High Schools students in Assin Districts in the Central Region, Ghana. The specific research objectives were to:

1) explore perceived causes of examination malpractices in WASSCE.

2) find out possible strategies to minimise examination malpractices in WASSCE.

\subsection{Significance of the Study}

The findings from the study will add to the body of knowledge regarding the causes and strategies to minimise examination malpractices among Senior High School Students. The findings will also help the Ministry of Education (MoE), Ghana Education Service (GES) and West Africa Examination Council (WAEC) to fight examination malpractices. Furthermore, the findings will help examination invigilators and supervisors to intensify their supervision during examinations.

\section{Methodology}

This paper adopted a descriptive survey design type. Thus, involved the collection of information from a large population. The target population consists of six public Senior High Schools in Assin Districts in the Central Region, Ghana. The sample for the study comprised Senior High School form 2 and 3 students and teachers who have taught in the Senior High Schools for at least a year. Proportional stratified and simple random sampling techniques were employed to select the respondents for the study. The sample size used for the study was 335 which was made up of 302 students and 33 teachers. The instrument employed for this study was a four-point Likert scale type questionnaire. This questionnaire comprised three sections and contained only closed-ended items. Section A of the instrument sought the background information of the respondents, Section B 
focused on the causes of examination malpractices (EM) and has 10 items and Section C which also has 10 items sought to solicit suggestions to minimise examination malpractices in Senior High Schools.

The content and face validity of the instrument was determined by experts in Test and Measurement who matched all the items of the questionnaire with the research questions to ascertain whether or not the instrument measured what it was supposed to measure. Their comments serve as a guide in making necessary corrections on the instrument. The reliability of the research instrument was determined using Cronbach's Alpha (r). The reliability coefficient of the students' instrument was 0.87 and that of the teachers' instrument was 0.82. In administering the instruments, two research assistants were employed to help. Returns were received from 334 (301 students and 33 teachers) respondents out of 335 respondents producing a response rate of 99.7 per cent for the study.

\section{Results}

Question One: What are the causes of examination malpractices in WASSCE in Assin Districts?

The findings are presented in Table 1.

Table 1: Opinion on Causes of Examination Malpractices in WASSCE in Assin Districts

\begin{tabular}{|l|c|c|c|c|}
\hline \multirow{2}{*}{ Statements } & \multicolumn{2}{|c|}{ Students } & \multicolumn{2}{|c|}{ Teachers } \\
\cline { 2 - 5 } & M & SD & M & SD \\
\hline 1. Indiscipline among students in schools & 2.7 & 1.09 & 3.03 & .78 \\
\hline 2. Insufficient student preparation for WASSCE & 2.99 & .97 & 3.31 & .89 \\
\hline 3. Willingness of students to pass WASSCE by all means & 2.96 & 1.00 & 3.10 & 1.05 \\
\hline 4. Lack of good study habits among students & 2.78 & 1.00 & 3.21 & .83 \\
\hline 5. Laziness on the part of students & 2.76 & 1.06 & 3.38 & .88 \\
\hline 6. Ranking of schools' performance in WASSCE & 2.52 & 1.08 & 2.74 & 1.16 \\
\hline 7. Uncompleted syllabus and lessons by teachers & 2.93 & 1.07 & 3.33 & .81 \\
\hline 8. Lack of effective supervision by invigilators & 2.43 & 1.09 & 2.48 & 1.09 \\
\hline 9. Inadequate learning resources and facilities in schools & 2.95 & 1.03 & 3.21 & .98 \\
\hline 10. Too many students writing in a small examination hall & 2.52 & 1.08 & 2.52 & 1.07 \\
\hline Mean of means & \multicolumn{2}{|c|}{2.75} & \multicolumn{2}{|c|}{3.03} \\
\hline
\end{tabular}

The results of the analysis in Table 1 indicate that majority of the respondents perceived the following items as the cause of examination malpractices; "insufficient students' preparation for WASSCE"(Students; $M=2.99, S D=0.97$, Teachers; $M=3.31, S D=.89$ ), "willingness to pass WASSCE by all means"(Students; $M=2.96, S D=1.00$, Teachers; $M=3.10, S D=1.05$ ), "inadequate learning resources and facilities in schools" (Students; $M=2.95, S D=1.03$, Teachers $M=3.21, S D=.98$ ), "Uncompleted syllabus and lessons by teachers"(Students; $M=2.93, S D=1.07$, Teachers; $M=3.33, S D=.81$ ), "ranking of schools' performance in WASSCE (Students; $M=2.52, S D=1.08$, Teachers; 2.74, $S D=1.16$ ). 
However, the respondents disagreed that lack of effective supervision by invigilators cause examination malpractices (Students; $M=2.43, S D=1.09$, Teachers; $M=2.48, S D=1.09$ ). Similar to student responses, the teachers also disagreed that lack of effective supervision by invigilators cause examination malpractices.

Research Question Two: What are the strategies to minimise examination malpractices in WASSCE in Assin Districts?

The findings are presented in Table 2.

Table 2: Opinion on Strategies to minimise

Examination Malpractices in WASSCE in Assin Districts

\begin{tabular}{|l|c|c|c|c|}
\hline \multirow{2}{*}{ Statement } & \multicolumn{2}{|c|}{ Students } & \multicolumn{2}{|c|}{ Teachers } \\
\cline { 2 - 5 } & $\mathbf{M}$ & SD & M & SD \\
\hline 1. Adequate coverage of the syllabi before the examination date & 3.00 & 1.08 & 3.49 & .76 \\
\hline 2. Provision of cars to supervisors for easy and quick movement & 2.34 & 1.14 & 2.38 & 1.23 \\
\hline 3. Good remuneration for teachers, invigilators, and supervisors & 3.02 & .96 & 3.18 & .82 \\
\hline 4. Examination should take off at the same time in exam centres & 2.92 & 1.00 & 3.10 & .99 \\
\hline 5. Proper seating arrangements to discourage copying & 2.79 & 1.04 & 2.74 & .91 \\
\hline 6. Ensuring that students sign attendance sheet whiles writing & 2.85 & .97 & 2.92 & .87 \\
\hline 7. Thorough checking of students before they enter the exam hall & 2.94 & 1.07 & 3.18 & .88 \\
\hline 8. Cancellation of entire examination results for mass cheating & 2.22 & 1.13 & 2.18 & 1.14 \\
\hline 9. Jail people who involved in examination malpractices & 2.39 & 1.89 & 2.42 & 1.26 \\
\hline 10. Public education on the effects of examination malpractices & 3.04 & .99 & 3.51 & .64 \\
\hline Mean of means & \multicolumn{2}{|c|}{$\mathbf{2 . 7 5}$} & $\mathbf{2 . 9 1}$ \\
\hline
\end{tabular}

The findings in Table 2 revealed that the majority of the respondents perceived the following strategies as a solution to minimise examination malpractices; "public education on effects of examination malpractices" (Students; $M=3.04, S D=0.99$, Teacher; $M=3.51$, $S D=.64)$, "good remuneration for teachers, invigilators, and supervisors" (Students; $M=3.02, S D=0.96$; Teachers; $M=3.18, S D=.82$ ), "adequate coverage of the syllabi before examination date" (Students; $M=3.00, S D=1.08$, Teachers; $M=3.49, S D=.76$ ), "examination taking off at the same time in examination centres" (Students; $M=2.92$, $S D=1.00$, Teachers; $M=3.10, S D=.99)$ "sign attendance sheet when writing examination" (Students; $M=2.85, S D=0.97$, Teachers; $M=2.92, S D=.87$ ). Nonetheless, the respondents did not perceive; "cancellation of entire examination results for mass cheating" (Students; $M=2.22, S D=1.13$, Teachers; $M=2.18, S D=1.14$ ), "provision of cars to examination supervisors for easy and quick movement" (Students; $M=2.34, S D=1.14$; Teachers; $M=2.38$, $S D=1.23$ ), and "jailing people who involved in examination malpractices" (Students; $M=2.39, S D=1.89$, Teachers; $M=2.42, S D=1.26$ ) as causes of examination malpractices.

Similar to student responses, the teachers also disagreed with the opinion that cancellation of entire examination results in mass cheating, provision of cars to examination supervisors and jailing people who are involved in examination malpractices as strategies to minimise examination malpractices. 


\section{Discussions}

The foregoing indicates the analysis of the data collected for the present study. As revealed in the findings, one of the main causes of examination malpractices in Senior High School was insufficient students' preparation for WASSCE. This could be that the students do not use their contact hours judiciously to learn and prepare for the examination. On this score, students that do not prepare for the examination would find dubious means to pass an examination and therefore engage in examination malpractices. This finding confirms the works of Makaula (2018) and Nyandwi (2017) who indicated that insufficient students' preparation for examination causes examination malpractices. Another cause as perceived by the students and teachers was the willingness of students to pass an examination by all means. This might be due to some external factors such as peer and parental pressure on their wards to obtain high grades to further their education and also to raise the image of their schools in terms of ranking or to boost their academic image. This finding is in harmony with Yusuf and Bamgbose (2015). In their findings, they indicated that the willingness of students to pass the examination at all costs made them engage in examination malpractices. Furthermore, it has been agreed by the teacher' and student' respondents that learning resources and facilities in SHSs are inadequate and do not promote effective teaching and learning to prepare students for WASSCE. Lack of teaching and learning resources; textbooks, teachers' handbooks, maps, science laboratory equipment, syllabi and physical facilities may hinder teaching and learning processes. Since the affected students would be writing the same examination with their peers who have available resources, they would employ means to pass their examination hence, examination malpractices. The finding confirms the work of Denga (2005) who contended that inadequate learning resources; textbooks, maps, laboratory equipment and other resources cause students to engage in examination cheating. Nevertheless, student' and teacher' respondents disagreed that lack of effective supervision by invigilators cause examination malpractices. This rating showed that invigilators supervise WASSCE effectively. The finding disconfirmed the work of Mutinda (2017) who found in his work that lack of effective supervision by invigilators cause exam malpractices.

The following were found as strategies to minimise examination malpractices in SHSs in Assin Districts, Central Region:

Public education on the effects of examination malpractices. The respondents agreed that one of the strategies to minimise examination malpractices is public education on the effects of examination malpractices. This suggested that when public education is intensified on the effects of examination malpractices, the canker would reduce. The finding confirms Fagbemi (2011) who indicated in his study that there should be public education on the effects of examination malpractices to reduce the menace. It was also revealed in the study that examination officials should be well remunerated to reduce examination malpractices in WASSCE. This finding might have emerged for a fact that examination officials are not paid well for their work, for that matter they involve 
themselves in examination malpractices by selling examination question papers and answers to the candidates. This finding is in line with Ene and Ursula (2015), who indicated in their study that government should enhance remuneration for teachers and examination invigilators/supervisors to minimise examination malpractices. Furthermore, it was agreed by the respondents that adequate coverage of syllabi before the examination date is one of the strategies to minimise examination malpractices in WASSCE.

It could be that students perpetrate examination malpractices when their teachers are not able to complete their syllabi and lesson before examination time. Since the students are to pass the examination to move further in the educational ladder or to secure jobs, they would surely devise means to pass their examinations, hence the involvement in examination malpractices. This finding supports the work of Bassey et al (2010) and Olatoye (2006) who revealed in their studies that the Syllabus should be made available and completed ahead of time of the examination.

However, similar to student respondents, teacher respondents also disagreed that cancellation of entire examination for mass cheating, provision of cars to examination supervisors and jailing of perpetrators of cheating were strategies to minimise examination malpractices. These findings were in disagreement with Onyechere (2008) and Olatoye (2006) who indicated in their findings that cancellation of entire examination when there is mass cheating, provision of cars to examination supervisors and jailing of perpetrators of examination cheating respectively were strategies to minimise examination malpractices.

\section{Conclusions and Recommendations}

Based on the findings of the study, it was concluded that in schools where a conducive environment and teaching and learning materials are not provided, academic performance always falls below what is expected by the school. To achieve academic success, students and teachers involve themselves in examination malpractices to raise the academic image of the school. Secondly, it was concluded that the students and teachers adopt various ways of involving themselves in examination malpractices in WASSCE.

Furthermore, it was concluded that when teachers are not able to complete the syllabi and lessons effectively and also the students themselves have not prepared adequately for examinations; they tend to engage in examination misconducts to raise the academic image of the school. Based on the findings and conclusions, the following recommendations were made: The school authorities should provide conducive teaching and learning environment to ensure effective academic work in schools and also heads of schools should make sure teachers complete their syllabi and lessons on time to prepare the students well for WASSCE. 


\section{Conflict of Interest Statement}

The authors declare no conflicts of interests.

\section{About the Authors}

Mr. Ben Adzrolo holds a Master of Philosophy degree in Measurement and Evaluation from the University of Cape Coast. He also has a Master of Education degree in Economics. Mr. Adzrolo has been teaching mathematics and science at a Basic School in Ghana for the past 10 years. He has also research skills in students discipline and examination malpractice.

Dr. Kenneth Asamoah-Gyimah is a senior Lecturer in the department of Education and Psychology at University of Cape Coast. Dr. Asamoah-Gyimah is a supervisor, a teacher and trainer when it comes to issues in Measurement, Assessment, Evaluation and Research.

Dr. Andrews Cobbinah is a lecturer in Measurement and Evaluation at the University of Cape Coast. He has been lecturing in the department of Education and Psychology for the past 8 years. He is well abreast in Research methods and Assessment in Education.

Dr. Annan-Brew is a co-supervisor for master students in the department of Education and Psychology at the University of Cape Coast. Dr. Ruth Annan-Brew have been teaching and researching Educational Statistics, research methods and educational measurement for 4 years.

\section{References}

Abuga, M. (2015). Teachers challenged to stand against examination malpractices. Retrieved August 18, 2016, from http://www.hivisasa.com/nyamir-a/news/105804.

Adams, O. U., \& Esther, O. D. (2013). Stakeholders' role in curbing examination malpractice in in Nigeria, retrieved from http://citeseerx.ist.psu.edu/viewdoc/download?doi=10.1.1.685.1083\&rep=rep1\&ty pe $=$ pdf

Adebayo, S. O. (2012). Students' perception of the role of parents in academic and continued examination malpractice. Academic Journals and Books. Retrieve May 2, 2014, from http://www.aeaafrican.org.

Anderman, E., \& Midgley, C. (2016). Most high school students' cheat. New York lives Science Review, 5-7.

Asante, K. (2014). Inclining factors towards examination malpractice among students in Takoradi Polytechnic, Ghana. Journal of Education and Practice, 5(22), 1-9

Asante-Kyei, M. \& Nduro, S. B. (2014). Causes of examination misconducts in Secondary Schools. Journal of Education and practice, 8 (20), 1-12.

Bassey, E. O., Bessong, F. E., Onete, U. O., Etim, C., \& Achigbe, M. O. (2010). An investigation into the forces behind examination malpractices in Nigeria: A 
challenge for secondary school education in the new millennium. Journal of Education Assessment in African, 4, 33-44

Bruno, U., \& Obidigbo, G. (2012). The counselling implications of examination malpractices among university undergraduates. Research Journal of Organizational Psychology and Educational Studies, 1(2), 199 - 202.

Busayo, I. (2008). Library intervention strategies against examination malpractices in a tertiary education institution. In N. Achebe, (Ed.), Library and Information Literacy for Higher Education. 2Pnd Ped. (pp. 65-89). Enugu, Nigeria: Nigeria Library Association.

Christian, N. J. (2015, July, 20). The alarming rate of examination malpractices in Ghanaian schools. Finder, p.2.

Chukwuemeka, I. V. (1982). The challenges of examination irregularities. Lagos: Public Relation Department, West Africa Examination Council.

Denga, D. I. (2005). Education at a glance: From cradle to tomb. Calabar: REP Ltd.

Dzakadzie, Y. (2015). Stakeholders' attitude towards examination malpractices in Senior High Schools in Volta Region of Ghana. African Journal of Interdisciplinary Studies $8,35-43$.

Ene, O. C., \& Ursula, C. N. (2015). Strategies for effective conduct for examination in a tertiary institution in Enugu State. Ife: Cardinal Crest ltd.

Fagbemi, A. (2011). Assessment and education malpractice. Proceeding of the 16th annual. Congress of the Nigeria Academy of Education held in the University of Jos, November 12-16.

Fayombo, G. A. (2014). Assuring quality in school practices and strategies. 1st National Conference of the Institute of Education, Olabisi Onabanjo University Conference Proceedings, p. 160-167

Isangedighi, A. J. (2007). Child psychology. Calabar, Nigeria: Eti-Nwa Associates.

Jega, A. M. (2006). Examination malpractices: Concept, causes, consequences and remedies. Education for Today, 6(2) 59-72.

Joshua, M. T. (2010). Examination malpractice: The monster in our midst. Paper presented at Intervention workshop for Teachers of English Language. Mathematics and Science subjects in Akwa Ibom State held in September. November.

Maheka, G. (2015). Nature and causes of examination malpractices in selected secondary schools in Kitwe District, Zambia. Lusaka, Zambia: The University of Zambia

Makaula, F. B. (2018). Perceived causes and methods of examination malpractice in the Malawian education system: A case study of secondary schools in the South East Education Division (SEED). Journal of Education and practice, 6 (20), 1-7.

Mutinda, G. (2017). Factors influencing pupils' involvement in examination malpractices in public primary schools. Journal of Education and practice, 6 (20), 1-10.

Nyamwange, C., Ondima, P., \& Onderi, P. O. (2013). Factors influencing examination cheating among secondary school students: A case of Masaba South District of Kisii County, Kenya. Elixir Psychology, 56, 13519-13524. 
Nyandwi, M. D. (2017). Determinants of poor academic performance of secondary school students in Sumbawanga District. Tanzania. Unpublished thesis.

Obo, F. E. (2008). Education stakeholders' attitudes towards examination malpractice and their preferred intervention strategies in Cross River State secondary schools' system, Nigeria. Unpublished PhD Dissertation). University of Calabar, Cross River State.

Olatoye, R. A. (2006). Checking the menace of examination malpractice: A call for more teaching and learning in schools. Retrieved October 15, 2010, from http://www.naere.org/journal/volums,/nco.1.

Omonijo, D. O. (2010). Parental influence onwards in an escalation of examination misconduct in Nigeria. European Journal of Social Sciences, 19(2), 297-309.

Onyechere, I. (2008). Examination fraud. Retrieved June 20, 2011, from http://www.egoboosterbooks.files.wordpress.com.

Otoo, A. (2018). Students' perception of causes of examination malpractices in Junior High Schools in Gomoa West, Central Region. Unpublished manuscript

Petters, J. S., \& Okon, O. (2014). Students' perception of causes and effects of examination malpractice in the Nigerian educational system: The way forward for quality education. Procedia - Social and Behavioral Sciences, 114, 125 - 129.

Saraj, A. (2006). Examinations in Pakistan. Lahore, Pakistan: Lahore Press.

Suleman, Q., Gul, R., Ambrin, S., \& Kamran, F. (2015). Factors contributing to examination malpractices at secondary school level in Kohat Division, Pakistan. Journal of Education and Learning, 9(2), 165-182.

Yusuf, F. A., Olufunke, Y. R., \& Bamgbose, O. R. (2015). Factors responsible for examination malpractices as expressed by undergraduates of Osun State University, Nigeria. Journal of Education and Practice, 6(33), 75-80. 
Ben Adzrolo; Kenneth Asamoah-Gyimah; Andrews Cobbinah; Ruth Annan-Brew

Creative Commons licensing terms

Author(s) will retain the copyright of their published articles agreeing that a Creative Commons Attribution 4.0 International License (CC BY 4.0) terms will be applied to their work. Under the terms of this license, no permission is required from the author(s) or publisher for members of the community to copy, distribute, transmit or adapt the article content, providing a proper, prominent and unambiguous attribution to the authors in a manner that makes clear that the materials are being reused under permission of a Creative Commons License. Views, opinions and conclusions expressed in this research article are views, opinions and conclusions of the author(s). Open Access Publishing Group and European Journal of Education Studies shall not be responsible or answerable for any loss, damage or liability caused in relation to/arising out of conflicts of interest, copyright violations and inappropriate or inaccurate use of any kind content related or integrated into the research work. All the published works are meeting the Open Access Publishing requirements and can be freely accessed, shared, modified, distributed and used in educational, commercial and non-commercial purposes under a Creative Commons Attribution 4.0 International License (CC BY 4.0). 